\section{University safety report hushed up?}

THE findings of a study by a senior inspector of the UK Health and Safety Executive (HSE) into health and safety in British universities may be controversial. Since the report of the study was submitted to the HSE last summer, it has not been made available to any of the organisations concerned with health and safety in universities. Neither the Committee of Vice Chancellors and Principals, nor safety officers in universities, nor the unions representing university employees have seen the report, even though they had all been led to believe that it would be available by the end of the summer of 1977.

The HSE puts the delay down to the length of time it has taken to consider the report and produce its own recommendations. But the general feeling outside the HSE is that the delay indicates that the report is embarrassing to someone. The unions, for example, feel that it may recommend major improvements to safety standards in universities which could cost of the order of $£ 40$ million.
The purpose of the study was to identify health and safety problems peculiar to universities. Prior to 1974, when the Health and Safety at Work Act was introduced, university employees had not been covered by health and safety legislation, so the HSE felt that a study to pinpont special problems would be helpful to its inspectors (who were accustomed only to the problems encountered in industry). Hospitals, schools and other new entrants under the 1974 act have also been subjected to similar studies.

The university study was conducted by Miss N. Curry, of the Scotland West Area Office She visited six universities chosen by the HSE in consultation with the CVCP-Leeds, Strathclyde, East Anglia, Cambridge, Swansea, and Salford-where she consulted heads of departments, union representatives and workers on the shop floor. By the Autumn of last year she had submitted her report to the HSE.

In contrast to the union's view that safety standards in the universities will have to be brought up to those in industry, the CVCP thinks the report is likely to suggest that special provision must be made for universities and research establishments, in accordance with the recommendations of the Robens Committee on Safety and Health at Work. In the CVCP's view a major problem in subjecting universities to the same health and safety requirements as industry is in determining the rights and obligations of students.

Both unions and university safety representatives, however, are anxious to see the report as soon as possible. The CVCP wants to revise its code of practice on health and safety and the unions are anxious to advise their members in the light of the report's recommendations. In a reply to a letter in the new year from John Akker, Deputy General Secretary of the Association of University Teachers, Bill Simpson, Chairman of the Health and Safety Commission, said that the report would be available sometime in the Spring. As yet, however, the HSE can give no clearer indication of when that will be.

Judy Redfearn

\title{
South Korea to raise investment in science and technology
}

SouTH Korea is planning major expansions in the development of science and technology. According to Choe Hyong-Sop, Minister of Science and Technology, the investment in science and technology is to be increased to $1.5 \%$ of the GNP by 1981 and $2.5 \%$ by 1991. The role of the Korean Science Institute in the development of the country' technology is to be expanded, and a vocational college established.

In a recent briefing session with President Pak Chong-hui, the Science Minister explained that the basic directions for technology policy are the "strategic development" of industrial technology and the "deepening of an atmosphere conducive to the development of science and technology". Considerable emphasis is being placed on the adaptation of advanced foreign technology to the needs and conditions of Korea, the attraction of private investment into the development, the training of technical manpower and the liberalisation of technology imports.

These aims are reflected by other Ministries. At last January's trade promotion conference, the Foreign Minister Pak Tong-chin said that efforts would be made to diversify sources of capital technology imports to Europe and the Middle East oil states. The Ministry of Commerce and Industry is simplifying the procedures and regulations governing the intro- duction of foreign technology. Concentrated support is to be given to a number of industries, including the chemical and metal-working industries; and several other industries, including electronics and the motor-vehicle industries, are to be developed into major export industries. Large enterprises will be encouraged to establish their own technological research institutes, and during the current year the Ministry will release $\$ 494,000$ from local currency loans and $\$ 1,300$ million from foreign exchange loans for laboratory equipment for such institutes.

Behind all these plans for expansion, however, one can sense a growing concern with energy supplies. South Korea is presently a coal producer, but importing of coal may become necessary as early as 1979. Oil is a major import, both for transport fuel, power generation, and for use in the important chemical industry. Plans are going forward for a new petrochemical

complex-the country's third-and new price stabilisation measures for essential commodities which should help hold down prices of certain types of oil and petroleum products. New sources of oil supplies are being sought in Africa and South America, in addition to the current Middle East suppliers (Iran, Kuwait, Saudi Arabia), in the hope of maintaining stable supplies and prices.

At the same time, the Energy and Resources Minister announced that no more oil-burning power stations will be undertaken; in future all new stations will be either lignite-burning, nuclear or tidal. In support of this policy, testing facilities for nuclear fuel processing with an annual uranium capacity of 10 tons are to be set up this year at the Taedok Specialised Technology Research Institute, and testing operations will commence by the end of the year.

Vera Rich

\section{Refusnik challenges withholding of his degree}

SincE 1976, academic brilliance has been a necessary but not sufficient condition for receiving a higher degree in the Soviet Union-a proper political outlook is equally, if not more, important. According to Article 24 of the regulations of the Higher Qualifications Commission (Vysshaya Attestat- sionnaya Kommissiya-VAK) which assesses a university's recommendation that such-and-such person be awarded the degree of Candidate (PhD) or Doctor, it is required that such persons have shown themselves to be among "those who follow the norms of communist morality and those who act 